\title{
THE BUDGET AS AN ADMINISTRATIVE PROGRAM
}

\author{
By Henry Brù̀re, \\ Chamberlain of the City of New York.
}

The year 1916 promises to be a memorable year in the development of budget practices in America. There are two conspicuous advanced steps now under consideration, both formulated by the New York Bureau of Municipal Research under the leadership of Dr. F. A. Cleveland. The first relates to the establishment in the state of New York of a definite budget procedure. This new procedure will center in the executive responsibility for determining financial policies and authorizing the use of public funds in the performance of state business, and is the first constitutionally prescribed budget procedure provided in American state government. The second relates to the further development of the budget practice in the city of New York, which during the past ten years has gradually evolved from chaos into a complex system of controlling expenditure of public funds through a meticulously detailed appropriation ordinance.

The bureau's proposals in both these fields mark, for the present, the culmination of the widespread thought that has recently been given to better control of the financial operations of the governments in America. I cannot do better than to commend to those interested in the scientific and at the same time the practical methods of budget making, a careful reading of the bureau's explicit statement of its proposals for New York City published in January, $1915 .^{1}$

The present volume contains numerous papers on the scientific aspects and theory of budget-making. My own purpose is to consider some of the practical problems involved in administering public finances and in determining on sound financial policies. First, let me review briefly the present status of budget-making in New York City, with a word of reference to the evolution of existing practices. I select New York City because it has taken

${ }^{1}$ Next Sleps in the Development of a Budget Procedure for the City of New York. 176 
leadership throughout the whole of America in breaking away from the confused and mischief-breeding methods of appropriation, once universal and still widespread, to a carefully conceived plan of correlating financial authorizations with work expectations and administrative responsibility. Because New York has been the pioneer, it is, in consequence, largely the victim of its own experimentation. As in every other government, departures from established practices, though difficult to make, once made, readily form themselves into routine, crystallized habits. New budget methods, instituted in the first instance to overcome specific abuses, and conceived one by one as these abuses were publicly recognized and sought to be corrected by official action, though of value in accomplishing their immediate purpose, have not aggregated themselves into a harmonious program correlating all the features of a proper fiscal policy.

It is this coördination and the consummation of a complete program that the Bureau of Municipal Research undertook in the submission of its notable document which now serves as at least the basis for the review of present practice and the formulation of a more broadly conceived practice for the future.

Ten years ago, appropriations in New York were in the nature of licenses to spend public funds, with only such restrictions as were imposed by general descriptive titles of appropriations or specific statutory requirements. It is conceivable that the form of budget prevailing in New York in 1906 was the result of a gradual accretion to a rudimentary financial structure. Never had an attempt been made to analyze or picture the character and variety of municipal activities, nor to correlate in any specific way the quantities of work to be done with the authorizations of funds by means of which the work was to be carried on. From time to time, by reason of legislative enactment, there had been added to the budget specific authorizations. This process continuing through a period of years finally evolved a great volume of appropriations which, with subdivisions into departments and occasional special classifications into items for salaries, wages and supplies, represented the form of budget in vogue in New York City until ten years ago."

2 The conditions prevailing in New York ten years ago still exist in many cities of the country, for clear budgetary statements are still the exception rather than the rule in America. 
In 1906 the first attempt was made to break through the haze of meaningless appropriations to discover what services were contemplated to be performed in pursuance of them. The historical method was adopted. That is to say, an analysis was made of past expenditures, and these past expenditures traced through vouchers, payrolls and books of account and through items of appropriation against which they had ultimately been charged. It was then seen at once that the process of evolution had not coördinated appropriations with the functional classification of activities in the departments. The practical result of this defect was that those who made the appropriations were not called upon to consider the sums requested or finally authorized, in terms of prospective activities or the specific needs of units of organization. Department heads recognized in authorizations no specific mandates of work to be performed, and consequently were free to utilize appropriations once obtained for whatever purposes might subsequently seem to them wise during the fiscal period to which the appropriations applied. There was no opportunity presented for the consideration of prospective charges against the funds of the city by taxpayers and civic bodies in terms of service desirable or otherwise. Budget making was merely a compromise between the compelling exigencies of work, or the political or personal persuasiveness of those making requests, and the political inexpediency of increasing too rapidly the city's annual outlays.

It was this condition which the first attempt at clarification in 1906 sought to remedy. This attempt consisted in the subdivision of appropriations by functions, according to groups or lines of activities. This functionalizing, or segregation as it came to be known, made possible the consideration of requests in terms of prospective service, and formed the basis of a specific agreement between the appropriation authorities and administrative heads to spend money allotted to them for the purposes indicated in the budget statement.

It was found, however, that functionalizing did not accomplish all that was expected of it. There still remained the possibility of developing forced emergencies which would inflate appropriations before the end of the period to which they were expected to apply, and the further possibility, in numerous cases, of utilizing sums which were allowed on the theory that they would be used for the 
purchase of supplies, for salaries, or vice versa. The door was left open for the subversion of appropriations intended for salaries to political purposes by withholding expenditures at the beginning of the year in order that the rate of spending might be increased at the end of the year under the promptings of a political campaign.

In short, there did not exist in the city of New York, as there did not exist generally throughout the cities in the country, the character of administrative responsibility or the method of administrative control in departments responsible for expenditures which would ensure the proper use of funds even when allotted under restrictions imposed by functional segregation. This condition, brought out in specific instances, prompted the institution of further devices for controlling administrative discretion through the appropriation ordinance or budget as it is called in the city of New York. These devices consisted in the:

1. Establishment of salary schedules under functions, showing the number of positions and rates of pay authorized for the performance of work;

2. Laying down the rule that, except in specifically indicated instances, the rate of salary expenditures must not exceed for any one month one-twelfth of the total annual allowance, thus preventing the particular exercise of discretion which customarily resulted in increasing the rate of employment prior to the preparation of the new annual estimate or the holding of a political primary or election.

Supply and equipment appropriations were treated in the same way. That is to say, they were analyzed in considerable detail according to the object of expenditure, so that department heads asking for funds were bound to utilize them for the purposes for which they had requested them, rather than for some later developed need or for a purpose not revealed at the time the authorization was made.

In addition to these fundamental restrictions on spending discretion, numerous administrative rules were laid down, as, for example, requirements that supplies should be purchased under specifications formulated by the board of estimate and apportionment, to prevent the unequal use of public funds for material of different grades for like purposes, and the prohibition of transfers between certain accounts because of abuses resulting from such transfers. This method of restricting the discretionary spending power of administrative heads developed to its height in the budget of 1913, when upwards of twenty-four conditions were laid down to control the use of appropriations. 
The method of budget appropriation which thus gradually developed, and which I have briefly outlined had this characteristic: It was conceived not by those responsible for administering the departmental affairs, but by those responsible for granting funds. It was prompted not so much by the desire to expedite the performance of public business, as to prevent age-long and conspicuous misuse of public funds which under lax organization and ineffective administration had become characteristic in New York as in other American cities. The purpose of the new budget method was in theory a negative purpose; that is to say, it was inhibitory rather than directive. But in practice this budget plan has worked a great many positive benefits. It has compelled department heads, in preparing their annual estimates, to scan the activities of their departments, not sectionally or in general terms, but item by item through the whole functional structure. It has served in a measure the purpose of the balance sheet, of an operating statement and cost accounts by affording an opportunity to match results with expenditures both to those responsible for obtaining results and to the appropriating authorities. It has revealed for the first time to the public the scope and range of city activities, and has made it possible in numerous instances to prevent unwise expenditures by compelling a detailed justification of requests in advance of authorizations.

The segregated budget plan of New York has operated to save millions of dollars which might have been spent without chicanery or desire for waste on the part of officials, but merely because they were permitted to obtain funds without careful self-analysis or analysis by special agencies which the segregated estimates have occasioned. But with its advantages the segregated plan has developed certain conspicuous disadvantages. These the bureau in its brochure points out in detail. I shall mention one or two to illustrate their character.

In the first place, the development of segregation produces in a city the size of New York with its vast variety of activities an appropriation ordinance of almost unwieldy proportions. Segregation by functions allots units of organization to specific activities which, if available, might profitably be utilized for service in a number or all of the divisions of a department. It ties down in advance authorizations for supplies according to prospective 
functional use, although it is generally impossible to estimate in advance the quantities of such supplies which will be required for each function with the result that there are uneconomical purchases or evasion of budget requirements. In other words, segregation results in a degree of regimentation which restricts and in a measure paralyzes the freedom with which the organization provided in the appropriations may be employed, or the funds for purchases may be utilized.

So much for the New York budget practice as it has developed during the years of experimental improvement. There are, however, numerous omissions in the present practice which it is now proposed to repair. These omissions relate chiefly to a method of stating appropriations, the observance of distinction between the budget and the appropriating ordinance, the inclusion in the budget submission of a statement of the means of its financing, and the submission for public information at the time of the promulgation of the budget ordinance of a statement of the city's finances, its fiscal operations during the previous period, and the facts regarding the city debt.

In New York City the practice has not prevailed which is elsewhere followed of including in the budget authorizations a complete statement of permanent improvements to be financed by the use of borrowed funds. Only such part of the expenditures for public improvements as are represented by salary and incidental charges are included in the appropriation ordinance, the contract and open market order expenditures being entirely omitted. These it is now proposed to include.

To facilitate the freer exercise of proper administrative discretion, and to provide a more complete financial instrument therefor, are the purposes of the proposed revision of New York City's budget practice. As outlined by the Bureau of Municipal Research, it is proposed to divide the annual financial instrument into two distinct parts: First-A budget prepared by the board of estimate and apportionment after analysis of departmental estimates, to be submitted by that board to the final appropriating body, the board of aldermen. Accompanying the budget, there are to be submitted: (1) A financial program for next year; (2) a work program, indicating the activities to be performed or services to be rendered pursuant to appropriations; (3) the method of 
financing authorizations; (4) statements showing the general financial condition of the city. Second-The appropriation ordinance proper. The budget, under the New York charter, does not become law until finally approved by the board of aldermen. The board of estimate and apportionment has, in practice, always prepared the budget in the form of an appropriation ordinance, the board of aldermen having authority only to reduce, not to increase allowances proposed. The Bureau of Municipal Research suggests that the board of estimate shall exercise a closer supervision over the expenditure of authorizations and that this supervision shall be continuous and not restricted merely to the itemization, terms and conditions of the appropriation ordinance. This supervision is to be exercised through the formulation of a work program, and through the subsequent allotment, monthly or otherwise, during the course of the year, by the board of estimate of funds from the appropriations to departments to carry out this work program. The budget or appropriation ordinance itself is to be changed in form. Instead of detailed items of appropriation by functions, departments are to be allowed appropriations in lump sums by objects of expenditure, $i$. e., for salaries, wages, equipment, etc.

In short, it is proposed to exercise through the appropriation ordinance control over the total expenditures for personal services and total expenditures for purchases and other contractual relations. It is not proposed that there shall be an attempt, as now, to exercise through budget appropriations control over the quantities of work to be performed or the functional use of authorizations, but that this control shall be exercised through the work program and correlated accounts and reports. By this device appropriations would be made for each department under general headings as the following:

Personal service;

Supplies-classified;

Purchase of equipment-classified;

Materials-classified;

Contract or open order service-classified;

Contingencies;

Fixed charges and contributions.

These appropriations would be made for an entire department, and not, as now, for each of the numerous subdivisions of a depart- 
ment. It would not be necessary, as now, for department heads to obtain specific authorization from the board of estimate to transfer funds from one account to another if the acutal requirements as developed during the year do not correspond with the estimated requirements as laid down several months before, when appropriations were determined. It would be possible, for example, to shift one employee from one division to another without restriction, except as I shall subsequently point out, and to purchase supplies in advance, making allotments to individual divisions as requisitions may determine. For an entire department it is urged there be established schedules of positions conforming to the standard groups and grades laid down by the board of estimate and apportionment in the standardization of city service now in progress. For supply appropriations, definite statements of the various classes of supplies required for the entire department are to be furnished, listed in accordance with the classificaton established by the board of estimate and apportionment, and these are to be purchased under standard specifications similarly prescribed.

Up to this point, in the form of the budget the difference between the present method and the proposed method consists merely in the elimination of the classification by functions and the treatment of departments as single administrative units. The purpose of this change is to expand the now restricted discretionary authority of department heads and to make more flexible the use of departmental organization. It is proposed also, to correct abuses developed through the attempt to control by functions the use of supplies in advance of their purchase, and to remove the confusion resulting from attempting to reflect the expenses of departments through appropriation accounts rather than through operating accounts.

A forward step is taken in the suggestion of the work program. As now prepared, there is lacking in the budget a specific understanding as to the quantities of work to be performed as a result of authorized expenditures. The amount of appropriations have been increasingly correlated with detailed explanations of proposed work to be performed, furnished verbally by department heads at hearings on the budget, or educed through examinations by accountants assigned to the investigation of requests by the budget making authorities. But these projected activities are 
not specifically formulated into written terms which may serve as the basis for supervisory control either by department heads with repsect to their subordinates, by the mayor with respect to departments under his control, or by the appropriating authorities with respect to all departments of the city government.

The bureau's proposal requires that there be included in the budget as submitted by the board of estimate a statement showing the expenditures by functional activities in detail corresponding to the detail required for proper administrative accounting control of departmental activities. Thus, for the bureau of child hygiene in the department of health, there would be shown proposed expenditures as follows:

Administration and other general business;

Medical inspection and examination of school children;

Examination and treatment of school children for diseases of nose, throat, teeth and eyes;

Technical instruction and direction of nurses;

Sanitary inspection of buildings, medical examination of children in institutions and day nurseries;

Investigation of persons and granting permits.

These expenditures would be classified, according to the bureau's suggestion, under six headings, as follows:

Expenses other than upkeep;

Upkeep of property and equipment;

Capital outlays;

Fixed charges other than pensions;

Pensions and retirement salaries;

Contingencies and losses.

The total of the authorized detailed expenditures in the work program for all divisions of the department would equal the total authorized for the department for salaries, supplies, equipment, etc. Thus, the appropriation ordinance would provide the means by which the work of the departments is to be done, and the work program would state in terms of proposed expenditures the uses to which these means were to be directed, according to the detailed functional activities of the department.

The bureau's plan proposes that there shall be made by a responsible member of the board of estimate and apportionment, quarterly allotments of funds appropriated for carrying out the 
work program as submitted by a department head. By this suggestion it is sought to maintain control over the specific use of funds, but it presents the difficulty of practically requiring, quarterly, a complete review by the appropriation authorities of departmental activities. A better method would be to make the appropriation and allotment for the entire year, and to authorize the execution of a work program throughout the year unless on the request of a department head it is desired to amend it within the limitation of the appropriation ordinance.

By whatever method it is finally determined to exercise control over activities, it is recognized as desirable that there shall be a close correlation between the appropriation of funds and the obligation to perform specific services. In my view it is not material whether the current revision of the work program for the year is submitted for the approval of the appropriating board, provided there is established adequate executive control over the use of funds whereby the responsible head of the government may be kept informed through reports of the current use of funds and the current results obtained. Department heads will be made to account for all deviations from the work program approved as a part of the budget authorizations when they come before the appropriating authorities in the following year for new allowances.

The success of the liberalized budget plan as suggested by the Bureau of Municipal Research would depend on the complete development and skillful use of the instruments of intelligence and control which have been and are now being provided in the government of the city of New York. These instruments consist of accounts and reports, agencies of investigation and inspection, and special advisory staffs established by the board of estimate and apportionment. The change in budget method is not in itself so important as the fact that the time has come when the relaxation of restrictions may be safely considered. There has come about in a remarkably short time a complete alteration of the attitude of the public officer to his executive responsibility. Instead of mere opportunism, evasion and compromise to which the average public officer of a decade ago was driven by political conditions or by lack of method and organization, department heads are now seeking to increase, day by day, the quality of service performed by the organization responsible to them, and to exercise increasingly effect- 
ive discretion with respect to the work for which they are responsible. Because of the exceptional character of its personnel, its conspicuousness, and the ease with which the public could deal with it, the board of estimate, the financial board of New York City, for years served as a shield between the political rapacity or administrative slovenliness of department heads and the public interest. Now, more and more, department heads are better prepared to exercise intelligence with respect to the administration of their departments than it is possible for a central body, such as the board of estimate, to acquire through personal contact or the advice of advisory staffs. The means which the board sought to develop for the purpose of exercising control over irresponsible and incompetent department heads are now the means which responsible and competent department heads themselves desire for effective control over their own work responsibilities. It is no longer necessary to compel departments to adopt modern accounting methods, it is no longer necessary to explain to departments the wisdom of adequate stores control, it is no longer a part of the work of reform to urge the establishment of cost records. These things are now desired by department heads as the means of assisting them in the discharge of their administrative responsibilities.

Thus, the restrictive purposes of the board of estimate and apportionment as expressed in the conditions of appropriations and minutely itemized authorizations of funds are coming to coincide with the administrative aims of departmental managers. To the extent to which these managers recognize the need for definite planning of work, the establishment of economical methods of operation, the close control of operative results, just to that extent will it be feasible to release them from the restraints of the present budgetary restrictions. When these things are accomplished, as they are now rapidly in process of accomplishment in New York City, there will be substituted for the inanimate control of an appropriation ordinance, the animate and directing control of a responsible and directing central executive department.

Because no machinery has as yet been developed for summarizing and interpreting currently the results of departmental operation, as reflected in accounting and service records, the chief instrument available to the mayor for control of departmental operations is the annual budgetary estimate. The estimate, however, has hereto- 
fore been inadequate because of its failure to provide a definite work program, and because it does not correlate results accomplished with expenditure. Accordingly, executive control continues to be exercised very largely through the consideration of incidents in administration, and through the planning of new activities or special developments of old activities to meet exigencies as they arise.

A continuous and progressive direction of the multifarious activities of the government has never been exercised by the chief executive and cannot now be exercised because of lack of organization as well as information through which it may be achieved.

In order that the board of estimate and apportionment might more adequately discharge the functions of financial control, it established two principal agencies. One, the bureau of standards, is charged with the formulation of standards for supply and equipment specifications, and the standardization of compensation for various grades and classes of service throughout the city. This work has resulted in providing the board with exceptionally comprehensive information regarding the needs, organization and methods of the various departments of the city government. In order that this information may be utilized advantageously, the bureau is now employed by the board of estimate and apportionment to review requests for funds which involve the payment of salaries and wages as well as the purchase of supplies and materials. In this way, as an incident to its appropriating power, the board of estimate has gradually acquired an authoritative position on the executive side of the city government as well as the appropriating side. Departments may not increase compensation or alter organization without the consent of the board obtained or denied as the result of an investigation by the bureau of standards.

The second agency is the bureau of contract supervision which is charged primarily with the review of specifications and the approval of contracts executed for public improvements. As an incident to this function the bureau is currently assembling cost data with respect to various public improvements and accumulating expert information regarding the structural equipment needs of the city. It has become, therefore, an agency of direction as well as appropriation in respect of those matters which involve new 
construction or the purchase of equipment chargeable against corporate stock.

These agencies which are subordinate to the board of estimate, the body of financial authority, provide information which is indispensable to intelligent executive direction. Their activity has developed naturally out of the more careful methods of budget preparation evolved by the board, and they are providing the means of supervising the administration of the budget which now occupies a considerable part of the attention of the board. The mayor has available to him now, as heretofore, the investigating staff of the commissioners of accounts. They, however, are not in a position to influence the organization and methods with the same compelling authority as the bureaus of the board of estimate which report on requests for appropriations.

In respect of the actual operation of the city government, therefore, the development of a systematic budget program in New York City has transferred, in considerable measure, the opportunity and means of detailed executive supervision from the mayor who is the chief executive of the city to the board of estimate and apportionment in which, though a member, he does not occupy a controlling position. This unbalanced condition will in a measure be obviated by the establishment of definite work programs to serve not only as a basis for appropriation, but as a basis for executive supervision.

The government of a great city, loosely constructed as most of them are, consists of a growing number of practically independent departments. These departments are each equipped with their special advisory technical staffs and are in a better position than the executive to determine on needs and policies. The practice has prevailed in New York, therefore, of executives relying upon department heads not only for administrative work, but for suggesting policies and for supervising their execution. Advantageous as is the practice in many ways of allowing, for example, initiative to department heads and giving latitude in the development of their own plans, there is this disadvantage: Each department seeks to enlarge its scope of activity and build up its own organization without regard to the conflicting needs of other departments. In putting in force a program of economy and efficiency, the chief executive of the city is confronted with the necessity 
not only of curbing the natural tendency to expand which exists in every department, but with the difficult task of finding the means, through better organization and more efficient methods, to provide additional services where they are imperatively required without increasing the aggregate cost of government. The advisory staffs of the board of estimate and apportionment, engaged as they are in the preparation and administration of the budget, will become increasingly well-equipped to devise and put into force improved processes and more effective organization.

In order to protect the executive responsibility of the mayor and at the same time to preserve the effectiveness of the budgetary control exercised by the board of estimate and apportionment, it is apparent that the mayor as the head of the corporation is called upon to take leadership in the direction of the fiscal activities of the board of estimate and apportionment of which he is chairman. Not to do so would result either in neglect of his responsibility to maintain active supervision over the administration of departments or duplication of the agencies of supervision. New York is therefore confronted with the necessity either of recognizing in the board of estimate a body of executive authority, or of revising its budget method to the extent of vesting in the chief executive responsibility for the preparation of the annual estimates and the supervision of their expenditure. This executive responsibility in preparing the budget estimate is one which will be exercised by the governor if the new plan of budget procedure laid down in the proposed new constitution of the state is put into effect. In the case of the state, as ultimately it is to be expected in the case of the United States, the chief executive will assume the responsibility for budget planning exercised by cabinets in parliamentary governments but heretofore exclusively exercised by legislatures and administrative departments in American state and city governments.

The board of estimate in New York is neither a cabinet nor a legislature. It is a body of officials individually responsible to the electorate and without collective responsibility for the administration of the city government. To achieve effective administration as well as competent financial supervision, the city of New York must presently choose between a government of board control and the transference of the agencies of supervision from the 
control of the appropriating authority to the control of the mayor. Under the present charter there are difficulties in the way of centering this control in the mayor, because a large part of the government of the city is under the direction of the borough presidents, who are members of the board of estimate, but who are not in any sense responsible to the mayor for the conduct of their departments.

It. is clear, however, that executive control cannot be intelligently exercised without the use of the power afforded in determining on appropriations and the opportunity which the investigation of requests presents for obtaining precise information regarding departmental needs, methods and activities.

As a practical matter, no formulation of a program of service is feasible in a great government which does not concern itself primarily with the community's ability to finance that program. The budget, therefore, is the basis upon which administrative planning and control must be predicated. A department of health must scheme out a complete program for health service, but it will never be able to execute that program until it is first able to persuade the appropriating authorities to grant funds with which to carry on the activities which the program demands. A growing city is continually presenting increasing demands for service. To meet these demands there are only two alternatives open:

1. Provision of increased funds, or

2. The more effective utilization of funds already granted.

An intelligent appropriating body will seek to demonstrate to an administrator his ability to perform increased service without adequate appropriations by more effective utilization of existing appropriations. To make such a demonstration it is necessary for the appropriating body to be informed in detail of the organization and administrative practices of the department in question, as well as of the service needs of the community. Recognizing this need, the present mayor of New York has sought in various ways to anticipate the demands of the board of estimate not only by directing department heads to refrain from asking for additional funds until every means apparent to them for effecting economies are exhausted. In addition to this he has opened the door to continuous investigation of departments by the board of estimate agencies, and has supplemented these investigations with studies 
made by special staffs reporting directly to him. The results of these efforts to achieve economy are reflected in the annual estimates of the departments and in the authorizations of funds based upon them. The budget, therefore, in New York City has become not only a means available to the legislative department of the city of New York, - the board of estimate and the board of aldermen,- for control of departmental expenditures, but furnishes as well the basis for executive supervision.

This is the purpose of a complete budget procedure. It should not merely be the expression of authorizations, but should be the summation of executive direction with respect to the scope of municipal activities and the methods of their administration. 